\title{
MENINGKATKAN TEKNIK LOMPAT JAUH MELALUI PENDEKATAN BERMAIN LOMPAT KANGURU
}

\author{
Mas'ud \\ SD Negeri 1 Ciherang Kabupaten Kuningann \\ Email: mas'ud12@gmail.com
}

\begin{abstract}
Abstrak
Tujuan dari penelitian ini adalah untuk miningkatkan teknik siswa. Subyek penelitian tindakan kelas akan diikuti oleh siswa kelas V SD Negeri 1 Ciherang Kec. Kadugede Kab. Kuningan Tahun pelajaran 2015/2016, dengan jumlah siswa 21 siswa yang terdiri dari 11 siswa laki-laki dan 10 siswa perempuan. Pelaksanan perbaikan aktifitas pembelajaran siswa berjalan cukup baik. Hasil dari siklus I pada pertemuan I nilai rata-rata adalah 1,90 dan pada pertemuan II nilai rata-rata adalah 2,71. Sedangkan hasil dari siklus II pada pertemuan I nilai rata-rata adalah 3,38 dan pada pertemuan II nilai rata-rata adalah 3,66 setiap pertemuan mengalami peningkatan yang cukup baik. Pelaksanaan perbaikan aktifitas pembelajaran guru berjalan cukup baik dengan nilai aktivitas guru 2,42 (dalam skala 1-5) pada siklus I pertemuan I dan pertemuan II menjadi 4,28. Sedangkan pada siklus II nilai aktifitas guru meningkat prestasi belajarnya dari putaran I adalah 3,57 dan putaran II adalah 4,71.
\end{abstract}

Kata Kunci: Pendekata, Bermain, Lompat, Jauh

Abstract
The purpose of this study is to improve students' techniques. Subjects of class action will be
followed by fifth grade students of SD Negeri 1 Ciherang Kec. Kadugede Kab. Kuningan
$2015 / 2016$ academic year, with a total of 21 students consisting of 11 male students and 10
female students. Implementation of improvement in student learning activities runs quite well.
The results of the first cycle at the first meeting the average value is 1.90 and at the second
meeting the average value is 2.71 . While the results of the second cycle at the first meeting the
average value was 3.38 and in the second meeting the average value was 3.66, each meeting
experienced a fairly good increase. The implementation of the improvement of teacher learning
activities went well with the teacher activity value of 2.42 (on a scale of $1-5)$ in the first cycle of
meeting I and meeting II to 4.28. While in the second cycle the value of teacher activity
increased his learning achievement from round I was 3.57 and round II was 4.71.

Keywords: Approach, Play, Jump, Away 


\section{PENDAHULUAN}

Proses pembelajaran yang diterapkan harus memperhatikan spesifikasi dari karateristik mata pelajaran serta perkembangan peserta didik sehingga tercipta suasana dilapangan yang kondusif, menyenangkan, efektif dan tampak semangat dalam mengikuti pelajaran. Proses pembelajaran yang diharapkan mengandung tiga ranah atau aspek yaitu kognitif, afektif, psikomotorik. Seiring dengan kemajuan di dunia pendidikan, muncul banyak metode pembelajaran yang dapat menjadi salah satu alternatif pemecahan dari permasalahan pembelajaran yang ada saat ini, sekaligus dapat digunakan untuk menciptakan suksesnya tujuan pembelajaran. Meskipun begitu, metode pembelajaran belum banyak diterapkan di sekolah karena guru belum banyak yang mempelajari metode-metode pembelajaran. Memberikan pembelajaran atletik yang menarik, praktis dan diminati siswa adalah tugas seorang guru, khususnya guru penjasorkes. Oleh karena itu guru harus mampu menyesuaikan kebutuhan yang berhubungan dengan siswa dan materi pembelajaran tersebut. Guru juga harus mampu menerapkan pendekatan, model, metode dan strategi yang sesuai dengan materi pembelajaran yang akan disampaikan.

Kenyataannya kemampuan siswa tidak sama dalam melakukan gerak dalam olahraga khususnya cabang atletik lompat jauh, seperti penulis mengamati saat mengajar lompat jauh di Kelas V SD Negeri 1 Ciherang Kec. Kadugede Kab. Kuningan dalam presentasi Teknik siswa menunjukan bahwa $85 \%$ siswa belum mencapai Kriteria Ketuntasan Minimum (KKM) yaitu 72. Hal ini menunjukan bahwa dalam pembelajaran lompat jauh mengalami masalah yang harus dicari jalan pemecahan masalahnya Kurang berkembangannya proses belajar mengajar penjasorkes di SD karena tidak adanya sarana dan prasarana pembelajaran yang tersedia disekolahan tersebut. Sehingga guru penjasorkes dalam melaksanakan proses pembelajaran bersifat monoton, tidak menarik dan membosankan maka siswa tidak memiliki semangat dan motivasi dalam mengikuti pelajaran penjasorkes.

Dari permasalahan yang dihadapi guru penjas dalam menyampaikan materi khususnya lompat jauh, maka peneliti merasa tertarik melakukan penelitian tindakan kelas (PTK) pada siswa kelas V SD Negeri 1 Ciherang Kec. Kadugede Kabupaten Kuningan.

Dari permasalahan diatas maka penting adanya penelitian tindakan kelas khusus pembelajaran lompat jauh untuk menciptakan semangat dan motivasi siswa sehingga siswa dapat tertarik dan menyenangi pembelajaran penjasorkes.Siswa mempunyai peluang untuk mengeksplortasikan gerak secara 
luas dan bebas sesuai dengan tingkat kemampuan yang dimiliki siswa serta bermanfaat bagi pertumbuhan dan perkembangan peserta didik.

\section{METODE}

Metode yang digunakan dalam penelitian ini adalah Penelitian Tindakan Kelas (PTK). Pada intinya PTK merupakan suatu penelitian yang akar permasalahannya muncul dikelas/di lapangan dan dirasakan langsung oleh guru yang bersangkutan sehingga sulit dibenarkan jika ada anggapan bahwa permasalahan dalam tindakan kelas diperoleh dari persepsi atau lamunan seorang peneliti (Arikunto, 2010). Dengan demikian penelitian tindakan kelas (Classroom Action Research) terkait dengan persoalan praktik pembelajaran sehari-hari yang dihadapi oleh guru. Prosedur kerja dalam penelitian tindakan kelas terdiri atas empat komponen, yaitu perencanaan (planning), pelaksanaan (acting), pengamatan (observing), dan refleksi (reflecting). Hubungan keempat komponen tersebut dipandang sebagai satu siklus. Subyek penelitian tindakan kelas akan diikuti oleh siswa kelas V SD Negeri 1 Ciherang Kec. Kadugede Kab. Kuningan Tahun pelajaran 2015/2016, dengan jumlah siswa 21 siswa yang terdiri dari 11 siswa laki-laki dan 10 siswa perempuan.

Instrumen yang digunakan sebagai pengumpulan data adalah lembar observasi/pengamatan sebagai nilai proses dan tes sebagai hasil akhir, serta lembar angket kuisioner sebagai data ketuntasan dari siswa. Data yang diambil dengan kegiatan observasi ini pelaksanaan tindakan saat pembelajaran. Bagaimana pelaksanaan pembelajaran lompat jauh apakah sudah sesuai dengan yang direncana atau belum.

Data yang dikumpulkan pada setiap kegiatan observasi dari pelaksanaan siklus penelitian tindakan kelas (PTK) dianalisi secara deskriptif. Teknik analisis tersebut dilakukan karena sebagai besar data yang dikumpulkan berupa uraian deskriptif tentang proses pembelajaran pada sub pokok bahasan lompat jauh. 


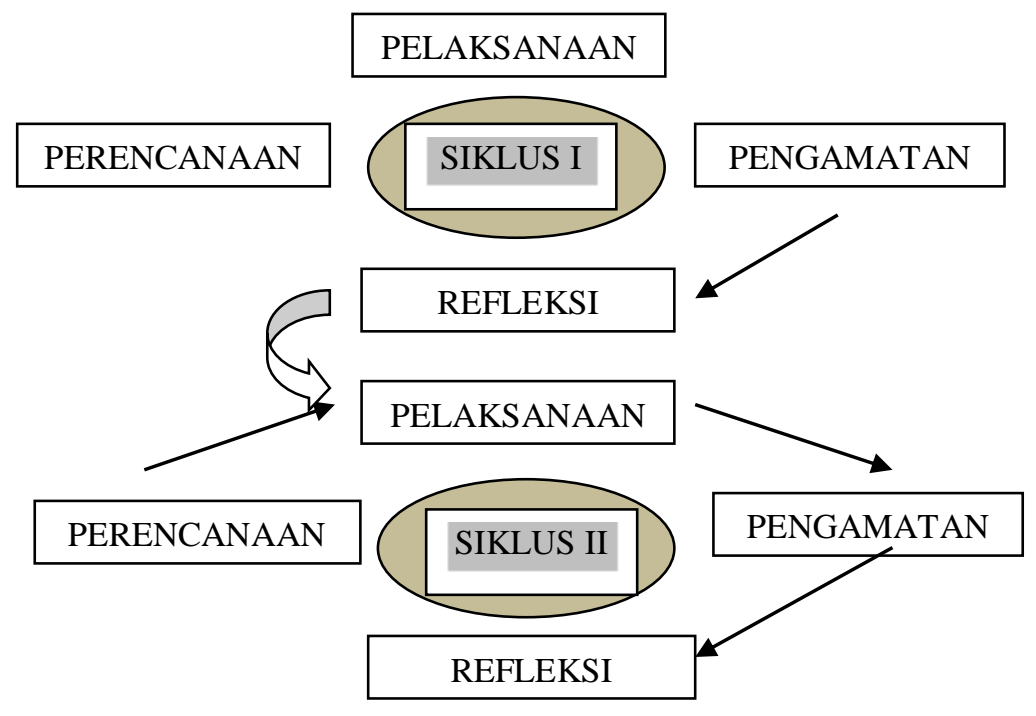

Gambar 1. Alur Siklus Penelitian Tindakan Kelas Sumber : Arikunto, 2008:16

\section{HASIL PENELITIAN}

Pada pelaksanaan perbaikan pembelajaran di siklus I dapat disimpulkan bahwa nilai rata-rata yang didapat adalah 72. Dari jumlah 21 siswa, ada 5 siswa yang belum mengalami ketuntasan belajar dan 16 siswa telah mencapai ketuntasan. Berdasarkan data tersebut dapat disimpulkan bahawa aktifitas siswa dalam perbaikan pembelajaran yang dilaksanakan pada siklus I, belum begitu memuasakan. Hal tersebut dikarenakan proses pembelajaran melalui pendekatan bermain lompat kanguru pada lompat jauh belum begitu mencukupi, yang mengakibatkan siswa masih ada yang bermain sendiri. Sehingga peneliti memutuskan untuk melanjutkan penelitian pada siklus yang ke II.

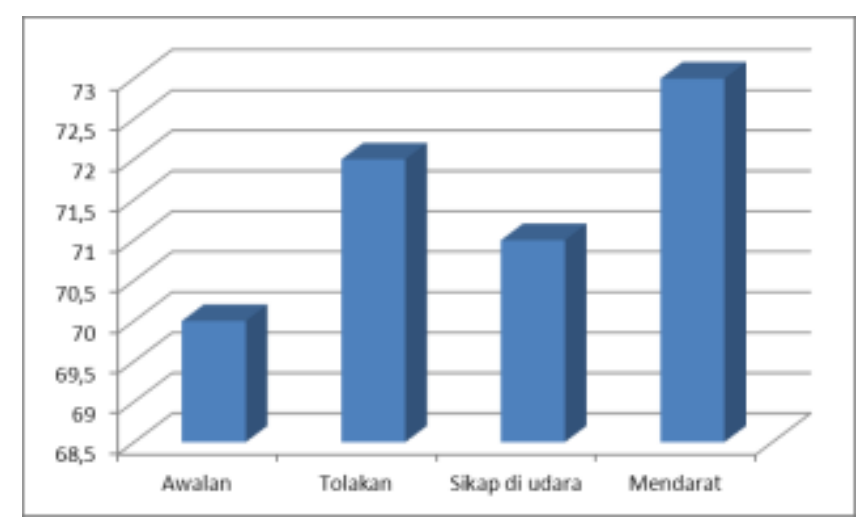

Grafik 1. Rata-Rata Nilai Hasil Tes Pembelajaran Siklus I 
Aktivitas pembelajaran yang kekurangan dalam pembelajaran maka dilaksanakan oleh guru pada pertemuan I mulai terlihat cukup baik, hal tersebut terlihat dengan perolehan nilai dari aspek penilaian yang hanya mencapai 3,57 dari skala nilai 1-5. pertemuan ke II dimana nilai rata- ratanya menjadi meningkat yaitu 4,71 pada skala nilai $1-5$.

Berdasarkan dari hasil tes

Setelah melaksanakan refleksi pembelajaran diatas kemudian dimasukan dalam grafik Teknik siswa sebagai berikut. dengan rekan sejawat dan membahas

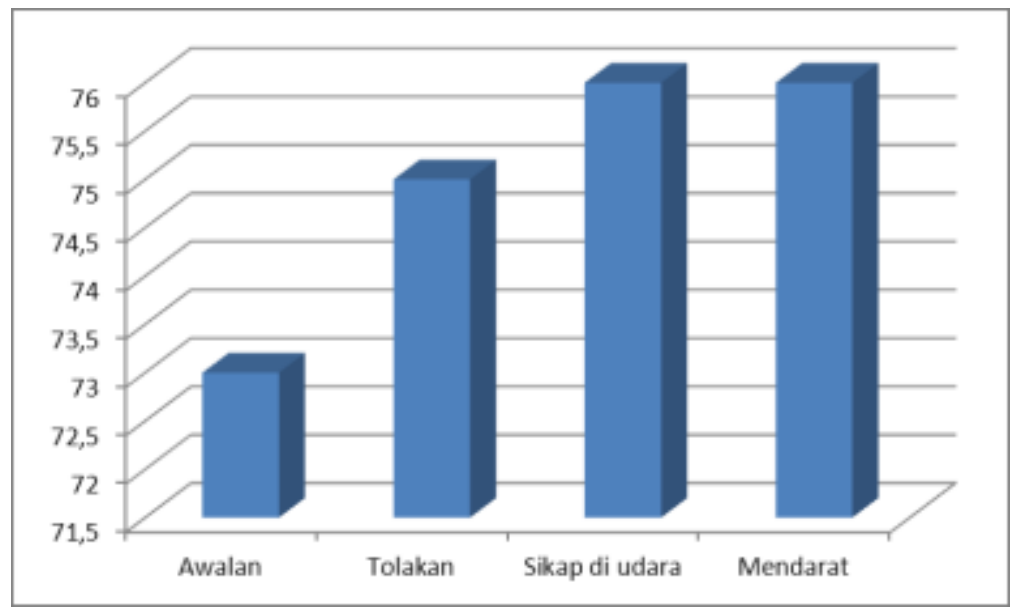

\section{Grafik 1. Rata-Rata Nilai Hasil Tes Pembelajaran Siklus II}

$$
\text { Pada pelaksanaan perbaikan }
$$
pembelajaran di siklus II dapat disimpulkan bahwa nilai rata-rata yang didapat adalah 75,04. Dari jumlah 21 siswa, ada 1 siswa yang belum mengalami ketuntasan belajar dan 20 siswa telah mencapai ketuntasan.
Berdasarkan data diatas dapat disimpulkan bahawa aktifitas siswa dalam perbaikan pembelajaran yang dilaksanakan pada siklus II mengalami peningkatan dan nilainya sesuai yang diinginkan. 


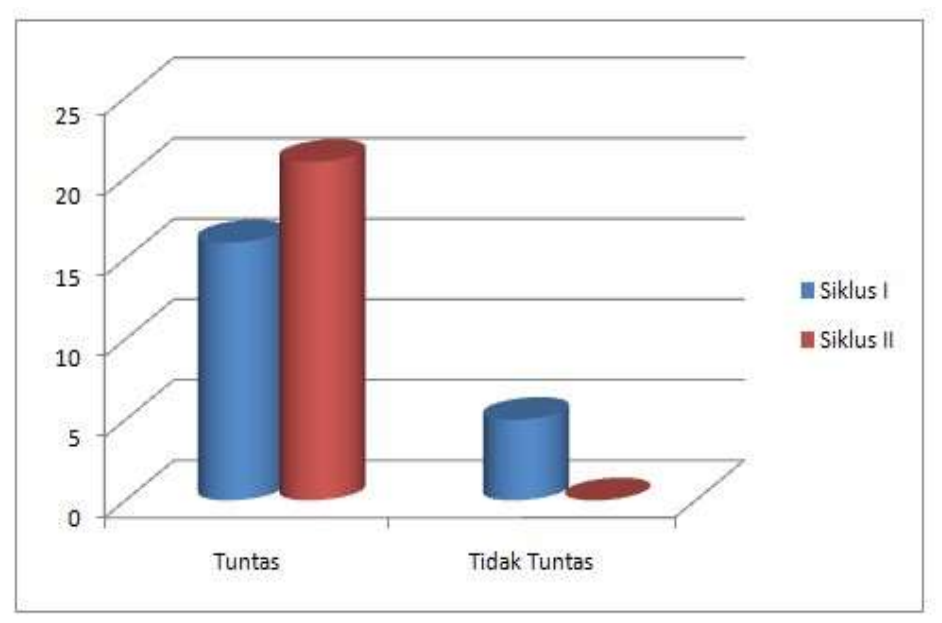

Grafik 3

Rekapitulasi Ketuntasan Belajar Siswa

Berdasarkan data dan diagram diatas dapat dilihat bahwa hasil tes pembelajaran siswa dalam proses pembelajaran mengalami peningkatan dengan dibuktikan yang pada siklus I siswa yang tidak tuntas 5 siswa dan yang 16 siswa tuntas meningkat yang tidak tuntas Cuma 1 siswa dan yang tuntas 20 siswa.

Pada pembahasan ini akan disajikan menurut hasil penelitian lompat jauh melalui pendekatan bermain lompat kanguru pada siswa kelas V SD Negeri 1 Ciherang Kecamatan Kadugede Kabupaten Kuningan mengalami peningkatan dalam pembelajaran lompat jauh. Pelaksanan perbaikan aktifitas pembelajaran siswa berjalan cukup baik. Hasil dari siklus I pada pertemuan I nilai rata-rata adalah 1,90 dan pada pertemuan II nilai rata-rata adalah 2,71. Sedangkan hasil dari siklus II pada pertemuan I nilai rata-rata adalah 3,38 dan pada pertemuan II nilai rata-rata adalah 3,66 setiap pertemuan mengalami peningkatan yang cukup baik. Pelaksanaan perbaikan aktifitas pembelajaran guru berjalan cukup baik dengan nilai aktivitas guru 2,42 (dalam skala 1-5) pada siklus I pertemuan I dan pertemuan II menjadi 4,28 . Sedangkan pada siklus II nilai aktifitas guru meningkat prestasi belajarnya dari putaran I adalah 3,57 dan putaran II adalah 4,71. Hasil tes pembelajaran ratarata nilai yang didapat pada pelaksanaan evaluasi perbaikan pembelajaran siswa pada siklus I adalah 72 dengan jumlah siswa yang belum tuntas 5 orang sedangkan yang tuntas adalah 16 siswa dari 21 siswa. Sedangkan pada rata-rata nilai yang didapat pada pelaksanaan perbaikan pembelajaran di siklus II adalah 75 dan 20 siswa telah mencapai ketuntasan dan 1 siswa tidak tuntas.

Peningkatan efektifitas pembelajaran lompat jauh pada siswa kelas V SD Negeri 1 Ciherang Kabupaten Kuningan terjadi karena dalam perbaikan pembelajaran 
secara konsekuen penulis melaksanakan aktifitas-aktifitas perbaikan pembelajaran dalam proses belajar mengajar antara lain sebagai berikut:

1. Menjelaskan materi pembelajaran dengan pelan dan menggunakan bahasa yang mudah dipahami oleh siswa.

2. Menggunakan metode permainan karena anak usia SD senang dengan bermain yaitu dengan pendekatan bermain lompat kanguru.

3. Pemanfaatan media yang tepat dan menarik

4. Pelaksanaan pemberian bimbingan yang sesuai.

5. Pemberian tugas dan latihan.

\section{SIMPULAN}

Berdasarkan hasil penelitian dapat disimpulkan bahwa melalui pendekatan bermain lompat kanguru, maka dapat diambil simpulan sebagai berikut:

1. Melalui penerapan pendekatan permainan bermain lompat kanguru dalam pembelajaran lompat jauh pada siswa kelas V SD Negeri 1 Ciherang Kec. Kadugede Kab. Kuningan Tahun Pelajaran 2015/2016, ditandai dengan meningkatnya ketuntasan prestasi belajar siswa. Hal ini sejalan dengan hasil data temuan yang diperoleh peneliti pada kondisi awal pra siklus ke siklus I sampai akhir siklus II.

2. Persentase nilai ketuntasan aktivitas siswa kelas V SD Negeri 1 Ciherang
Kec. Kadugede Kab. Kuningan, pada kondisi awal pra siklus 36\% atau sejumlah 8 siswa yang mencapai ketuntasan belajar dari 21 siswa keseluruhan, kemudian pada siklus I terjadi peningkatan sebesar $76 \%$ atau sejumlah 16 siswa dan pada akhir siklus II meningkat sebesar $95,2 \%$ atau sejumlah 21 siswa yang mencapai ketuntasan belajar.

Berdasarkan hasil penelitian dapat disimpulkan bahwa melalui pendekatan permainan tradisional lompat skipping dapat meningkatkan efektitas belajar siswa dan mengoptimalkan dalam pembelajaran PJOK pada materi khususnya materi lompat tinggi pada siswa kelas V SD Negeri 1 Ciherang Kec. Kadugede Kab. Kuningan Tahun Pelajaran 2015/2016

\section{DAFTAR PUSTAKA}

Achmad munib, dkk. 2007. Pengantar Ilmu Pendidikan.Semarang: UPT MKK Universitas Negeri Semarang.

Achmad Sugandi, dkk. 2007. Teori Pembelajaran. Semarang: UPT MKK Universitas Negeri Semarang.

Aip Syarifuddin, dkk. 1992. Pendidikan Jasmani dan Kesehatan. Jakarta: Departemen pendidkan dan kebudayaan.

Bismo Suryatmo, dkk. 2006. Pendidikan Jasmani, Olahraga, dan 
Kesehatan untuk kelas IV. Jakarta:

PT. Widya Utama.

Bismo Suryatmo, dkk. 2006. Pendidikan

Jasmani, Olahraga, dan

Kesehatan untuk kelas V. Jakarta:

PT. Widya Utama.

Buku Panduan penulisan skripsi fakultas

ilmu keolahragaan, 2011.

Universitas Negeri Semarang.

Catharina tri anni, dkk. Psikologi Belajar.

Semarang: UPT MKK Universitas

Negeri Semarang.
Eko Suwarso, dkk.2010. pendidikan

jasmani, olahraga, dan kesehatan.Jakarta: PT. Arya Duta

Juari, dkk. 2010. Pendidikan jasmani, Olahraga, dan Kesehatan. Jakarta: CV Bina Pustaka.

Sugiyanto dan Sudjarwo. 1991 Perrkembangan dan belajar gerak, modul 1-6. Jakarta: Departemen Pendidikan dan Kebudayaan.

Syarifudin. 2009. Tahapan Belajar Gerak dan Pembelajaran Pendidikan Jasmani. 